\title{
Świadek na wystawie. Świadectwa w nowych muzeach historycznych
}

Maria Kobielska

TEKSTY DRUGIE 2018, NR 3, S. 295-308

DOI: $10.18318 /$ td.2018.3.20

Dodstawą tez, jakie stawiam w tym artykule, jest przeprowadzony przeze mnie przegląd wystaw stałych polskich muzeów historycznych, licznie zainaugurowanych w ostatnich latach i wykorzystujących środki „nowego" muzealnictwa, o różnorodnie i sugestywnie organizowanej przestrzeni (określam je w swoich badaniach jako „urządzenia do pamiętania”). Trudno byłoby wskazać wśród nich wystawę, która w ogóle nie odnosiłaby się do świadectwa i nie wykorzystywała w swojej konstrukcji figury świadka - takie odwołania można określić jako powszechne. Najintensywniej są jednak one dziś obecne, według mojego rozeznania, w muzeach, których zakres tematyczny wyznacza II wojna światowa i jej reperkusje. Co ciekawe, w muzeach o szerzej zakrojonych ramach czasowych motyw świadectw najczęściej pojawia się również przede wszystkim właśnie w tych

1 Obszernie uzasadniałam wprowadzenie tego terminu w tekście Urządzenia do pamiętania, "Studia Kulturoznawcze” 2017 nr 1 (11), s. 55-68.
Maria Kobielska - dr, adiunkt w Katedrze Antropologii Literatury i Badań Kulturowych na Wydziale Polonistyki UJ, gdzie współtworzy też Ośrodek Badań nad Kulturami Pamięci. Zajmuje się najnowszą literaturą i kulturą polską w kontekście pamięci, przeszłości i polityki. Ostatnio opublikowała książkę Polska kultura pamięci wXXI wieku: dominanty. Zbrodnia katyńska, powstanie warszawskie istan wojenny (2016). Kontakt: maria.kobielska@ gmail.com 
„wojennych" sekcjach. Dla przykładu w Muzeum Śląskim w Katowicach, które ukazuje szczegółowo przeszło sto lat historii regionu do 1989 roku i które posługuje się medium świadectwa bardzo oszczędnie, znalazło ono swoje miejsce właśnie przy planszach dotyczących Górnego Śląska pod okupacją hitlerowską, a zwłaszcza problematyki Volkslisty. Nie do końca zgodnie z objaśnieniem, które zapowiada możliwość zapoznania się z „relacjami świadków", zobaczyć możemy tam wideo ze wspomnieniami Emmy Jureckiej z Chorzowa, sięgającej pamięcią do swojego dzieciństwa. Okres powojenny i czasy nam najbliższe zostały z kolei przedstawione na wystawie bez wykorzystania świadectw.

Taka jest też zasadniczo reguła - choć oczywiście nie bezwyjątkowa - budowania wystaw w analizowanych polskich muzeach. Może się to wydawać właściwie zaskakujące: w końcu świadectwa dotyczące czasów późniejszych byłoby potencjalnie łatwo pozyskać, a ich użycie mogłoby budować głębszy ogląd okresu postrzeganego już jako zakończona historia, ale stosunkowo najbliższa. Z kolei świadectwa dotyczące czasów wcześniejszych, jak dwudziestolecie międzywojenne, są oczywiście trudniej dostępne, ale tym bardziej potencjalnie atrakcyjne i przybliżające okres wysuwający się poza obszar pamięci komunikacyjnej - życia pradziadków i prapradziadków współczesnych zwiedzających. Wyobrazić by sobie można na wystawach świadectwa dotyczące zarówno indywidualnego oglądu znanych i dramatycznych wydarzeń, jak i sposobu organizacji dnia codziennego.

Anna Ziębińska-Witek, wskazując na okoliczności pojawienia się świadectw w muzeach w latach 70. i 8o., zaznacza, że ich włączenie w ekspozycję „stało się jedną z głównych strategii eksponowania doświadczenia muzealnego"2 w odniesieniu do wystaw dotyczących Zagłady. Z kolei autorka świeżo wydanej książki poświęconej tej tematyce, Steffi de Jong, wskazuje, że proces ten intensyfikuje się później - na przełomie XX i XXI wieku, dotycząc przede wszystkim świadectw Zagłady i II wojny światowej ${ }^{3}$.W polskich muzeach świadectwo pojawia się również przede wszystkim w potencjalnie „traumatycznym” kontekście, wbrew hipotetycznie nakreślonym wyżej

2 A. Ziębińska-Witek Historia w muzeach. Studium ekspozycji Holokaustu, Wydawnictwo UMCS, Lublin 2011, S. 249.

3 S. de Jong The Witness as Object. Video Testimony in Memorial Museums, Berghahn, New YorkOxford 2018, s. 6; tejże Who is History? The Use of Autobiographical Accounts in History Museums, w: Museums and Biographies: Stories, Objects, Identities, ed. by K. Hill, Boydell and Brewer, London 2012, s. 296. 
możliwościom - zwykle w odniesieniu do II wojny światowej i związanych z nią trudnych doświadczeń osób mówiących. Dlatego też w moich dalszych rozważaniach będę odwoływać się przede wszystkim do dwóch muzeów, które wojnę mają za główny temat, czyli najstarszego i najmłodszego we wspomnianej serii XXI-wiecznych muzeów historycznych: Muzeum Powstania Warszawskiego (Warszawa, otwarte w 2004 roku) i Muzeum II Wojny Światowej (Gdańsk, 2017; zaznaczam, że analizując to muzeum, odwołuję się w tej chwili do pierwotnego kształtu jego wystawy).

Na potrzeby tego tekstu przyjmuję proste i być może zachowawcze rozumienie świadectwa jako relacjonowania minionych wydarzeń przez ich uczestnika lub uczestniczkę - ofiarę, bohatera, widza, postronnego czy (rzadko) sprawcę, odwołujące się oczywiście do pamięci indywidualnej". Powstrzymuję się więc od poruszania potencjalnie fascynujących zagadnień mniej oczywistych i niekiedy metaforycznie rozumianych świadectw, takich jak te składane przez „rzeczowych świadków”, świadków nieludzkich. $\mathrm{Na}$ wystawie świadectwo zawsze występuje jako fragment - o czym dalej - oraz jako cytat z utrwalonej w jakimś medium działalności świadczenia. Najczęściej wykorzystywane w muzeach formy, do których będę się przede wszystkim odwoływać, to świadectwo wideo i nagranie audio; nieco na boku będę musiała pozostawić rzadziej spotykane odwołania do innych wizualnych postaci świadectwa (jako świadectwo fotograficzne) oraz świadectw tekstowych.

W swoim klasycznym już tekście James E. Young zwraca uwagę na kluczowe zapośredniczenia, jakie wiążą się z „tworzeniem świadka” przez medium świadectwa wideo. Jak pisze, pamięć jest w tym przypadku „ujednolicana i podwójnie zorganizowana: najpierw w narracji mówiącego, potem w ruchu narracji stworzonym przez samo medium"5. Forma wideo zapewnia (albo: narzuca) m.in. wskazanie początku i końca świadectwa oraz jego jednokierunkowy temporalny przebieg. Analogicznie trzeba powiedzieć, że „tworzenie świadka” na wystawie muzealnej będzie procesem o co najmniej potrójnej organizacji: poza poziomem narracji mówiącego i narracji medium (np. wideo) w grę wchodzi narracja samej ekspozycji - czyli sposób, a więc poetyka i polityka, „wystawienia świadka”. Być może o jeszcze bardziej

4 Por. M. Marszałek Świadectwo, w: Modi memorandi. Leksykon kultury pamięci, red. M. Saryusz-Wolska, R. Traba, Scholar, Warszawa 2014, s. 473.

5 J.E. Young Holokaust wświadectwach filmowych i świadectwach wideo. Dokumentowanie świadka, przeł. T. Łysak, "Literatura na Świecie” 2004 nr 1/2, s. 246. 
skomplikowanej sytuacji należałoby mówić, gdy na wystawie używane jest świadectwo dodatkowo przetworzone (np., co częste, powstały niezależnie od wystawy film dokumentalny zmontowany z fragmentów świadectw). De Jong analizuje w szczegółach tę „potrójną organizację” świadectwa wideo, mówiąc w tym kontekście o jego „muzealizacji”, na którą składają się złożone procesy reprezentacji i medializacji, dotyczące zarówno etapu włączania świadectw wideo do muzealnych kolekcji, ich wystawiania i nadawania im znaczeń w ramach wystawy ${ }^{8}$.

Zacytowanie świadectwa na wystawie w każdym przypadku oczywiście będzie jego przetworzeniem. Ziębińska-Witek zauważa w tym kontekście, że „wywiady, podobnie jak cała ekspozycja, są pod ścisłą kontrolą kuratorów" ; za najważniejsze konsekwencje ich umieszczenia na wystawie uznaje ich uwiarygodnienie (ich autorytet i autentyczność stają się niekwestionowalne) oraz konieczną fragmentaryzację - z oczywistych względów nie są one eksponowane w niekiedy wielogodzinnej całości, a w (najczęściej tematycznych) wyimkach. Badaczka wskazuje na konieczne, nieneutralne decyzje towarzyszące konstruowaniu wystawy, a dalej, omawiając sposoby prezentowania świadectw w wybranych muzeach, rozważa je przede wszystkim ze względu na to, w jakim stopniu przyciagają uwagę do wypowiedzi świadka. Wskazuje na różne efekty umieszczenia monitorów na ścianach, w specjalnych kioskach oraz zaaranżowania na sposób kinowy ${ }^{\mathbf{1 0}}$. De Jong pisze, że wybór świadków, wybór fragmentów spośród świadectw oraz ich edycja mają nadać im „strawny kształt”11, odpowiadający przyzwyczajeniom zwiedzających. W efekcie powstają, by tak się wyrazić, filmowe porcje o długości nieprzekraczającej 10-20 minut, eksponujące „najbardziej ekscytujące i najlepiej powiedziane fragmenty wywiadów", zmontowane w taki sposób, że tworzą się z nich „krótkie filmy biograficzne lub zapętlone serie krótkich, anegdotycznych epizodów"12.

\footnotetext{
6 S. de Jong The Witness as Object..., S. 5.

7 Por. tamże, s. 19-20.

8 Por. tamże, s. 27.

9 A. Ziebińska-Witek Historia w muzeach..., S. 252.

10 Por. tamże, s. 251.

11 S. de Jong Who is History?..., s. 301.

12 Tamże, s. 302-303.
} 
Zacznę systematyzację obserwacji dotyczących sposobu wystawiania świadectw od prostszego przypadku świadectwa audio: kluczowa pozostaje kwestia sposobu nagłośnienia wypowiedzi przez głośniki albo przez słuchawki, a ponadto natężenie i jakość dźwięku, z których wynika komfort słuchania. Głośniki zasadniczo zapewniają większe wyeksponowanie materiału niż słuchawki, po które zwiedzający może, ale nie musi sięgnąć; takie wyróżnienie świadectwa audio nie jest jednak często spotykane. W wypadku świadectw audio znaczenie będzie więc miało przede wszystkim to, w jakim stopniu wysłuchanie ich zależy od decyzji zwiedzającego - mogą się one okazywać mniej lub bardziej „fakultatywne” - oraz to, w jakim stopniu zwiedzający będzie do tego zachęcany. Pierwszą kwestię może ilustrować różnica między umieszczeniem na wystawie nagrania świadectwa, które słychać od razu po sięgnięciu po słuchawki (najczęściej w zapętleniu) a sytuacją, gdy słuchawki towarzyszą infoboksowi, a świadectwo może zostać uruchomione, o ile akurat na nie trafi zwiedzający w nierzadko obszernej bazie danych. Drugą zaś - rozwiązywanie umieszczenia nagrań audio w scenografii wystawy w bardziej interesujący sposób niż przy wykorzystaniu neutralnej formy zwykłych słuchawek.

Oczywisty przykład pochodzi z wystawy Muzeum Powstania Warszawskiego, którą otwierają zapadające w pamięć budki telefoniczne. Podnosząc słuchawkę stylizowanego na przedwojenny aparatu, zwiedzający mają "dzwonić" do jednego z pięciorga świadków, których zdjęcia i dane personalne - jak również krótkie hasła stanowiące niejako nadane w ramach wystawy tytuły świadectw - widoczne są nad telefonami. Obok każdego telefonu znajduje się tabliczka z kilkoma przyciskami, opisanymi przez pytania, na które odpowiada świadek (np. „jak Pani wspomina przejście przez kanał?”, "Czy zapamiętała Pani jakiś szczególny dzień z Powstania?"). Zwiedzający podejmują tu kilka decyzji: czy zatrzymają się przy tym fragmencie wystawy; kogo ze świadków wybiorą; ilu (i którego) z tematycznych fragmentów wysłuchają. Jednocześnie sugestywna aranżacja budek telefonicznych i ich umieszczenie na samym początku wystawy bardzo podnoszą ich znaczenie i przykuwają do nich uwagę; tych pięcioro świadków wstępnie ustanawia podmiot muzealnej opowieści o powstaniu (i dlatego np. tak istotne jest to, że są to wyłącznie żołnierze i żołnierki).

Atrakcyjność i skuteczność tego rozwiązania odpowiada, jak sądzę, za fakt, że jest ono jedną z najczęstszych pochodzących z MPW inspiracji pojawiających się w innych muzeach. Telefony „retro” ze wspomnieniowymi świadectwami zamykają np. wystawę w Muzeum Powstań Śląskich 
w Świętochłowicach. Choć taka aranżacja wykorzystuje tylko część funkcji telefonu-rekwizytu (zwykle nagrań nie wybiera się przy użyciu tarczy; iluzja "rozmowy” wydawałaby się też dość słaba ze względu na jej jednostronność), jest atrakcyjnym sposobem interakcji z wystawą i, dalej, nawiązywania więzi ze świadkiem-rozmówcą.

Wyprowadzony z tych obserwacji parametr obowiązkowości/fakultatywności danego świadectwa w doświadczeniu muzealnym wydaje się również kluczowy w wypadku świadectw wideo, fundamentalnie silniej - dzięki obrazowi - oddziałujących ${ }^{13}$.Te z nich, które nagłośnione są tylko przez słuchawki, a zwłaszcza te, które dodatkowo wymagają odnalezienia i wyboru w bazach danych, są oczywiście najmniej wyeksponowane - co nie oznacza, że nie będą mogły odgrywać ważnej roli we wspomnianym doświadczeniu, jednak potencjał ich oddziaływania na nie będzie mniejszy. Większą siłę nadać im mogą atrakcyjne rozwiązania ekspozycyjne (jak w poprzednim wypadku telefony). Wystawa Muzeum II Wojny Światowej jest wprost naszpikowana takimi świadectwami, do których dostęp zapewniają różnie, często znacząco, zaaranżowane stanowiska; w niektórych miejscach stają się one centrum projektowanego doświadczenia.

Pierwsza w chronologii zwiedzania sala, w której świadectwo nie jest uzupełnieniem innych treści, ale wybija się na plan pierwszy, znajduje się w sekcji zatytułowanej „Agresja ze Wschodu” (w części „A więc wojna!”). Na środku pomieszczenia znajdują się ekspozytory, wyświetlające w zapętleniu filmy wypełnione świadectwami Polaków wspominających 17 IX 1939 roku i następujące dni we wschodniej części przedwojennej Rzeczpospolitej. $\mathrm{Na}$ pionowych, niedużych ekranach widać ich twarze na zmianę z ilustrującymi ich świadectwa obrazami, np. fotograficznymi, a także zaczerpnięte z ich słów "tytuły” kolejnych części wypowiedzi (np. „Sowieci przekroczyli granicę”, „Krew płynęła rynsztokami”). Ekrany są umieszczone dość nisko, co skłania do zajęcia przygotowanego miejsca siedzącego, a w konsekwencji tworzy, jak sądzę, wrażenie bliskości czy familiarności, ale także kruchości świadka, na którego wyjściowo patrzymy niejako z góry.

Inny wariant rozegrania podobnej sytuacji pokazuje sekcja „Masakry miejscowości” w części „Terror”, z jeszcze większą wyrazistością zbudowana wokół świadectw. Scenografia tworzy tu oś czasu zbudowaną z pulpitów prezentujących (poprzez wpuszczone w nie gablotki z eksponatami, tekst, fotografie) kolejne odwetowe pacyfikacje. W trzech miejscach linia ta, zachowując

Por. A. Ziebińska-Witek Historia w muzeach..., s. 251. 
ciągłość, załamuje się, budując przestrzenie dla ekranów. W efekcie ekran jest jakby „chroniony” przez ścianki powstałej półszafki czy niszy, twarze świadków są wyraźniej widoczne dzięki osłonięciu od światła, a zwiedzający może, zbliżając się do nich, wejść pod ten sam „daszek", tworzący nieco intymniejszą przestrzeń. Przy każdym ekranie jest tylko jedna słuchawka - projektuje to doświadczenie filmowego „spotkania” ze świadkiem na osobności, twarzą w twarz. Wszyscy świadkowie to osoby, które ocalały z masakr i rzezi ludności cywilnej; pięcioro z ośmiorga to Polacy, a oprócz nich Serb, Czeszka i Francuz. Identyczność rozwiązań ekspozycyjnych, jukstapozycje świadectw i jednakowy rytm scenografii drastycznej narracji tworzą silne wrażenie wspólnoty doświadczenia, będące jedną z zasad wystawy MIIWŚ, do której powrócę przy omówieniu kolejnego przypadku.

Sądzę, że przy całej sugestywności powyższych świadectw istotna różnica - z punktu widzenia warunków doświadczenia muzealnego - zachodzi jednak między wyżej wzmiankowanymi sytuacjami wyboru a takimi, w których samo znalezienie się w danym miejscu wystawy czyni ze zwiedzającego, choćby na chwilę, odbiorcę wyeksponowanego świadectwa. Oczywiście taki ekran wiszący na ścianie muzealnego pomieszczenia również można zignorować, jednak jednocześnie oddziałuje on wizualnie, przyciągając wzrok do twarzy świadka, i organizuje audiosferę, wypełnia fragment przestrzeni ekspozycyjnej jego głosem. W Muzeum Powstania Warszawskiego tuż obok inicjalnego stanowiska z telefonami, w drodze do dalszej części ekspozycji, umieszczono krótki, odtwarzany w zapętleniu wyjątek ze wspomnienia Jana Nowaka-Jeziorańskiego; świadek przekonuje zwiedzających o konieczności wybuchu powstania („To miało charakter eksplozji, wybuchu wulkanu, któremu nie można zapobiec... To było dla mnie zupełnie jasne, że to musi wybuchnąć" - nawet mimo wiedzy, że zryw nie osiagnie swoich politycznych i militarnych celów), ustanawiając kolejną niepodważalną zasadę narracji muzeum. Miejsce, w którym znajduje się ekran, zapętlenie i krótkość fragmentu (bardzo łatwo wysłuchać go od początku do końca, a jeśli spędzi się w pobliżu więcej czasu - przez powtórzenia zapamiętać go bardzo dokładnie) nadają mu tego szczególnego znaczenia. Wyraźnie widać w tym wypadku użycie świadectwa i autorytetu świadka jako instrumentu do ustanowienia specyficznego, politycznie nacechowanego znaczenia; fragment świadectwa znajduje się na wystawie wyraźnie nie ze względu na nie samo, a na jego wartość jako argumentu. W szczególnie wyrazisty sposób ilustruje to kwestię władzy nad świadectwem, jaka realizuje się przez sposób jego wystawienia; w efekcie, jak zauważa de Jong, jest ono podporządkowane „semantycznej 
strukturze muzeum”14, do której się adaptuje, stając się przekaźnikiem „oficjalnej narracji historycznej"15.

Wielkość ekranu, pomieszczenia, kontekst, w jakim jest umieszczony, sposób zaplanowania miejsca dla odbiorców to oczywiście kluczowe czynniki kształtujące muzealne doświadczenie świadectwa; jak sygnalizuje Ziębińska-Witek, „mniejsze pomieszczenia pozwalają odwiedzającemu na bardziej intymny kontakt z narratorem, duży ekran nadaje wypowiedziom status publicznego oświadczenia”16. W Muzeum II Wojny Światowej kolejną zaaranżowaną silnie "wokół świadectw" sekcją jest ta zatytułowana „Przesiedlenia, deportacje, wypędzenia" (z lat wojennych) - a także ściśle paralelnie urządzona „Wielka przebudowa: migracje i granice” (dotycząca skutków zakończenia wojny). W każdym z tych wypadków z pomieszczenia wprowadzającego temat polityki wymuszającej przesiedlenia, którego podłoga to mapa pokazująca ich kierunki, przechodzi się do trzech pomniejszych salek. Obok każdego z wejść w ścianach umieszczono ślepe drzwi, odsyłające do opuszczanych przez ludzi domów, przed wejściami - infoboksy, nad nimi zaś - ekrany wyświetlające serie zdjęć. Każde z tych niewielkich wnętrz jest urządzone zasadniczo tak samo: panuje w nim półmrok, ściany i sufit mają czarny kolor, a centralny, przyciągający wzrok element to ekran, na którym wyświetlane są dokumentalne montaże filmowe. Ich zawartość to przede wszystkim świadectwa złożone współcześnie przez osoby pamiętające dane wydarzenia, zdarzają się jednak także materiały złożone z kronik filmowych (jak w wypadku akcji „Heim ins Reich”, której historię przybliża lektor na tle dokumentalnych ujęć) i cytaty z powstałych poza muzeum filmów dokumentalnych (jak Różai Jan Hanny Etemadi w pomieszczeniu dotyczącym Zamojszczyzny). Tego rodzaju dokumentacja występuje więc na równych prawach, wymiennie ze świadectwami; sądzę jednak, że to one nadają tu główny ton.

Warunki doświadczenia świadectwa są wyraziste: zwiedzający wchodzą do niewielkiego, ciemnego pomieszczenia, w którym niejako „zastają" świadka w trakcie nieskończonego procesu świadczenia. Twarze świadków ostro odcinają się w ciemności, ich głosy wypełniają pomieszczenie pozbawione innej ścieżki dźwiękowej; ich słowa stają sięgłówną treścią ekspozycji, w tym miejscu nie konkurują z nimi żadne obszerniejsze plansze, tytuły, objaśnienia

14 S. de Jong, Who is History?..., s. 306.

15 Tamże, s. 305.

16 A. Ziebińska-Witek Historia w muzeach..., s. 251. 
czy multimedia. Świadectwa za sprawą wyboru i montażu rozpadają się na najwyżej kilkuminutowe fragmenty zorganizowane na ogół wokół jednego momentu czy wręcz anegdoty z historii świadka. Nieuchronnie jego ekspresja, charyzma, a także warunki techniczne wpływają na reakcje zwiedzających, którzy wyjątkowo tylko będą wysłuchiwać całego materiału. Ważne okazuje się więc to, że niektóre świadectwa słychać dobrze, inne okazują się zbyt ciche, a ich odbiór niekomfortowy, że niektórzy świadkowie mówią z większą swadą i bardziej dynamicznie etc. Z zestawu fragmentów świadectw zapamiętuje się tylko niektóre, np. te „najmocniejsze”, jak w jednym z ostatnich pomieszczeń (poświęconym tematowi powojennych przesiedleń na Wschodzie) - wstrząsającą opowieść Elsy Reisone o śmierci jej siostry Lidiji i następującym obłędzie matki. Opisane przez Younga środki - a więc poetyka - "narracji mówiącego" i „narracji medium” stają się w muzealnej ramie, łączącej wiele świadectw, nie tylko elementami "procesu tworzenia świadka”, za każdym razem pojedynczego i wyjątkowego, ale też instrumentami wirtualnej rywalizacji między świadectwami o oddziaływanie na doświadczenie zwiedzających. Sytuację tę uznać można za nieco dwuznaczną.

Treści świadectw są zestawione w ciągu, są równoprawne, ale nie zawsze uzgodnione, przebijają przez nie odmienne doświadczenia i oceny (np. opowiadając o tzw. powojennej „repatriacji”, Irmina Uruska mówi o jej tragicznych warunkach i głodzie, a zabierający głos po chwili Władysław Zajewski przeciwnie). Nie tworząc uspójnionej narracji o przeszłości, nie wchodzą też w proste zależności z dominantami kultur pamięci, do których mogłyby się odnosić, a niekiedy wprowadzają w świadomość ich użytkowników treści do pewnego stopnia "niestosowne" - jak w wypadku świadectw dawnych „dzieci Zamojszczyzny", w których powraca wątek niechęci do powrotu do polskiej rodziny i mocnej identyfikacji z niemieckością („,jestem Niemką, Bebel Rossmann" - uobecnia w czasie teraźniejszym swoją tożsamość dziewięciolatki dzisiejsza Barbara Paciorkiewicz; „mój dom jest w Koblencji”, wspomina swój bunt po powrocie do polskiej matki Alojzy Twardecki).

Świadectwa przyczyniają się w szczególny sposób do wykształcenia dwóch spośród głównych zasad ekspozycji Muzeum II Wojny Światowej - pierwsza to zdominowanie narracji przez perspektywę cywilną i codzienną. Gdy w Muzeum Powstania Warszawskiego wszyscy główni świadkowie byli walczącymi powstańcami, w Muzeum II Wojny Światowej nie użyto ani jednego świadectwa znanej osoby, należącej do elit politycznych czy wojskowych, i bardzo zredukowano wypowiedzi żołnierzy. Na wystawie pojawiają się z kolei biografie „zwykłych ludzi”, potraktowane tak, aby zaprzeczyć tej rzekomej 
zwykłości - opisane równie szczegółowo i za pomocą takich samych środków, jak w wypadku słynnych postaci historycznych, z dodatkowym efektem autentyczności i uprzywilejowania dzięki możliwości zabrania głosu przez samego świadka. Po drugie zaś, wystawę porządkują powracające zestawienia, paralele sugerowane przez sam sposób aranżacji wystawy, a tworzące się niekiedy także między doświadczeniami ludzi z przeciwnych stron frontów.

Wszystkie powyższe uwagi o sposobach eksponowania świadectw dotyczą także ich swego rodzaju przetwarzania - w sensie trzeciego poziomu „potrójnej organizacji" mowy świadka na wystawie muzealnej. Świadectwo sfragmentaryzowane, zestawione z innymi, umieszczone w konkretnym miejscu szerszej wystawy staje się czymś nieco innym, a jego doświadczenie - którego warunki przygotowuje dla zwiedzających ekspozycja - jest w znaczący sposób odmienne od zapoznawania się ze świadectwem w warunkach archiwalnych ${ }^{17}$ czy oczywiście, by użyć formuły Doriego Lauba, „bycia świadkiem procesu bycia świadkiem"18. Różnicowanie to szczególnie wyraźnie widać w wypadku pewnych usterek ekspozycyjnych świadectw, którym może np. brakować źródła (nie zawsze wiadomo, czy mamy do czynienia ze świadectwem nagranym specjalnie na potrzeby muzeum, zaczerpniętym z zewnętrznej, i jakiej, bazy historii mówionej, czy też np. z kolejnym stopniem przetworzenia przy wykorzystaniu fragmentu uprzedniego wobec wystawy filmu dokumentalnego); przy uważnej lekturze muzealnych świadectw można znaleźć zapewne nieuniknione błędy opisu (np. w Muzeum II Wojny Światowej ta sama osoba opisana jest raz jako Sybille Kolka, w innym miejscu jako Martha Werner; z kolei świadectwo Diny Herzberg, więźniarki Stutthofu, zostało użyte w instalacji dotyczącej masakry w Palmnikach bez wskazania jej nazwiska).

Wspomniane przetwarzanie świadectw na wystawach przybiera też jeszcze bardziej ewidentne formy - gdy stają się punktami wyjścia nowych muzealnych montaży. Prosty, ale uderzający przypadek to odczytywanie tekstowego świadectwa przez aktorów czy lektorów: porównując efekt takiego działania do świadectwa audio, w którym głos świadka jest nośnikiem autentyczności, trzeba stwierdzić hybrydyczność powstałej dźwiękowej instalacji. Jej oddziaływanie zależy teraz w sporej mierze od sposobu głosowego wykonania, który nie zawsze będzie neutralny (krańcowym wypadkiem byłoby

17 W sprawie trudności w obcowaniu ze świadectwem wideo w muzeum, jeśli chce się wysłuchać go z pełną uwagą i w całości por. S. de Jong The Witness as Object..., s. 26.

18 D. LaubZdarzenie bez świadka: prawda, świadectwo oraz ocalenie, przeł. T. Łysak, "Teksty Drugie” $2007 \mathrm{nr}$ 5, s. 118. 
pojawienie się maniery czy egzaltacji). Bardziej skomplikowane będą takie montaże, w których świadectwo jest tylko jednym z wielu elementów; za przykład może posłużyć filmowa instalacja z Muzeum II Wojny Światowej ukazująca powstania (ponownie na zasadzie równouprawniającej jukstapozycji: w Warszawie w 1943 i 1944 roku, w Paryżu, na Słowacji, w Pradze). Zdjęcia $\mathrm{i}$ archiwalne nagrania filmowe zostały zmontowane $\mathrm{z}$ cytatami ze świadectw - tylko jednak w niektórych wypadkach zidentyfikowanymi, w innych nie możemy nawet mieć pewności, czy rzeczywiście słyszymy urywek świadectwa, czy po prostu tekst utrzymany w jego poetyce. Wizualno-akustyczny montaż wyświetlany jest na dużym ekranie w ciemnej, tajemniczej sali projekcyjnej. Jego warstwa dźwiękowa dominuje „powstańczą” część ekspozycji (jej dźwięki docierają także do sąsiadujących pomieszczeń). Pojawia się w niej muzyka - niekiedy poważna, fortepianowa czy podniosły chór, niekiedy, jak w wypadku powstania paryskiego, wręcz skoczna - oraz głosy lektorek i lektorów, interpretujących fragmenty wspomnień. Urywki wspomnień czytane przez lektorki i lektorów są bardzo krótkie, nierzadko krótsze od pełnego zdania, rwane i pozbawione początku i ciągu dalszego, nie składają się na spójną opowieść. W części dotyczącej powstania warszawskiego słychać np. lekko drżący, zapadający w pamięć męski głos, mówiący: „ten mały ciagle płakał, oni go tam uspokajali, że już nie będzie widział trupów, nie będzie się palić"; potem młode głosy, sugerujące (choć to, rzecz jasna, inscenizacja), że są to wypowiedzi żołnierzy: „uważałem, że jak żyję, to mam prawo walczyć”, „chcieliśmy być wolni i wolność sobie zawdzięczać”, „ludzka nędza taka straszna... patrzą na nas wilkiem, bo to przez nas, powstańców, stało się to nieszczęście, a oni cierpią najwięcej". Poetyka świadectwa, wychodząca od czasowego dystansu, miesza się tu z poetyką uobecniania, uteraźniejszania, bezpośredniej relacji - staje się więc konwencją, którą wystawa może się dość dowolnie posłużyćc ${ }^{19}$.

19 Osobną kwestią pozostaje nasuwający się w tym kontekście skrajny przypadek, jakim byłoby fingowanie świadectwa. Choć muzea obficie posługują się aluzjami do konwencji autentyczności, nie natknęłam się w swoim przeglądzie na jednoznaczny przypadek prezentowania obiektu niebędącego świadectwem w taki sposób, aby zdecydowanie zasugerować jego przynależność do tej grupy. Być może najdalej w tę stronę idzie wystawa w Fabryce Emalia Oskara Schindlera (filia Muzeum Historycznego Miasta Krakowa), gdzie, jak pisze Zuzanna Bogumił, "na murze krakowskiego getta [zamieszczono] listy dzieci żydowskich. [...] Wykaligrafowane dziecięcą rączką literki wzmacniają przekaz i tak silnie emocjonalnych świadectw. Nie są to jednak oryginalne dokumenty, ale relacje świadków, spisane przez nich po wojnie i na potrzeby wystawy opracowane w interesującej graficznie formie" (Z. Bogumił Miejsce pamięci versus symulacja przeszłości. Druga wojna światowa na wystawach historycznych, „Kultura i Spo- 
Powyższe uwagi prowadzą mnie do postawienia nieuniknionych pytań dotyczących już nie tylko poetyki i polityki, ale i etyki „wystawiania świadków" (choć w żadnym razie do rozwiązania wiążących się z nimi dylematów). Jak pisze de Jong, samo włączenie świadectw w obręb wystaw muzealnych można widzieć jako „bezpośrednią odpowiedź” na wezwania, aby „wysłuchać głosów ocalałych i traktować je z szacunkiem"20, wezwania, które były formułowane szczególnie dobitnie od początku tzw. ery świadka. Sytuacja, gdy świadectwa pozostają w archiwach i tylko wyjątkowo mogą znaleźć odbiorców, jest więc problematyczna - a upowszechnianie ich w muzeach może być sposobem radzenia sobie z tym problemem. Jednocześnie poddanie świadectwa władzy kuratora stanowi szczególne wyzwanie etyczne.

Umieszczone w muzealnych kontekstach świadectwa są zawsze w jakiś sposób używane - mają służyć, na różne sposoby, celom wystawy. Zdaniem Tony'ego Kushnera cena,jaką płaci się za użycie - nawet w najbardziej świadomy i staranny sposób - świadectw na muzealnej wystawie historycznej, to utrata pojedynczości świadectwa konkretnego świadka, który próbuje poprzez opowieść nadać sens swojemu życiu²1. Świadectwa oglądane w muzeach zlewają się ze sobą w zuniwersalizowaną całość - szerszą, spójną historię, którą opowiada wystawa; to w nią ma angażować się zwiedzający. De Jong tłumaczy w tym kontekście, że każda „indywidualna historia tylko reprezentuje wszystkie możliwe podobne historie"22 . Badaczka zauważa, że choć oddawanie głosu świadkom miałoby prowadzić do pluralizacji perspektyw, narracyjnej wielopodmiotowości, dyferencjacji konstruowanej pamięci kulturowej, w której obręb włączone zostają bardzo różne elementy, to jednak proces ten ma swoje granice. Analiza wystaw ujawnia kryteria, według których wybierani są sami świadkowie i którym podlega sposób prezentacji świadectw. Efektem jest więc - raczej niż „heterogenizacja pamięci kulturowej” - „homogenizacja wielogłosowości” potencjalnie zawartej w świadectwach ${ }^{23}$.

łeczeństwo" 2011 t. 55, nr 4, s. 155). Na możliwość przywołania tego przykładu w kontekście fingowania świadectwa zwróciła mi uwagę Justyna Kowalska-Leder.

20 S. de Jong The Witness as Object..., s. 11.

21 T. Kushner Oral History at the Extremes of Human Experience: Holocaust Testimony in Museum Setting, "Oral History” 2001 Vol. 29, No. 2, s. 92.

22 S. de Jong Who is History?..., s. 304.

23 S. de Jong The Witness as Object..., s. 18. 
Wydaje się, że ten opis może być w pewnym stopniu adekwatny również w takim wypadku jak analizowane wyżej Muzeum II Wojny Światowej, pełne nieuzgodnionych ze sobą na podstawowym poziomie świadectw. Tu również świadkowie prezentowani są w „tematycznych grupach”, ich świadectwa składają się na uogólnione obrazy historycznych wydarzeń, a w ostatecznym rozrachunku podporządkowane są wspomnianej zasadzie paralelizacji; ich pojedynczość schodzi więc na dalszy plan. Jednocześnie jednak wystawa osiąga za ich pomocą również ten pierwszy wskazany przez badaczkę cel jest urządzeniem, które pluralizuje pamięć o II wojnie światowej. Akceptacja tak rozumianej praktyki używania świadectwa pociąga za sobą pytanie o jej granice - o to, kiedy zdecydujemy się uznać coś za nadużycie. Punktem wyjścia do takiego namysłu mógłby stać się stosunkowo dobrze znany ${ }^{24}$ przypadek wykorzystania wspomnienia Marka Edelmana w Muzeum Powstania Warszawskiego - świadectwo zostało tu ukontekstowione w taki sposób, że kontekst, po pierwsze, konstruuje pamięć sprzeczną z pamięcią świadka, po drugie, znacznie nad nim dominuje

Druga, poza nadużyciem, potencjalnie problematyczna kwestia wiąże się z ogólnym sposobem działania nowych muzeów, zasadzającym się na wyborach, decyzjach i względnej sprawczości zwiedzających, którzy konstruują swoje doświadczenie muzeum, korzystając z mnogości dostarczanych przez muzealne urządzenie możliwości, ale nigdy nie wykorzystując wszystkich. Stąd kontakt ze świadectwem staje się jedną z tych - uatrakcyjnianych, a zawsze niekoniecznych - możliwości. Świadectwa w nowych muzeach służą fingowaniu spotkania, poruszeniu, stworzeniu wrażenia bliskości - spotkanie to jest jednak chimeryczne, kontakt niekoniecznie uważny, możliwość przerwania - stała i wpisana w logikę zwiedzania wystawy. Ceną za upowszechnienie jest uczynienie z nich obiektów wielostronnie zależnych: od obudowania kontekstem, sposobu ekspozycji, miejsca na wystawie, od zdolności przyciągania uwagi, wreszcie od częściowo przypadkowej decyzji zwiedzającego. Muzeum buduje doświadczenie osobistego kontaktu np. ze świadkiem - naszym „rozmówcą telefonicznym”; tym samym, koniecznie i paradoksalnie, otwiera możliwość dość drastycznego w ramach tej iluzji gestu odłożenia słuchawki w pół słowa fantomowego "rozmówcy”.

24 Już wkrótce po otwarciu Muzeum Powstania Warszawskiego pisał o tym Tomasz Żukowski (tegoż Muzeum, „Bez dogmatu” 2005 nr 66). Dokładnie omawiam tę kwestię w mojej książce Polska kultura pamięci: dominanty. Zbrodnia katyńska, powstanie warszawskie i stan wojenny, Wydawnictwo IBL PAN, Warszawa 2016, s. 186-189. 
Jednocześnie, przy wszystkich tych znakach zapytania, muzea są chyba jedną $\mathrm{z}$ tych nielicznych przestrzeni ${ }^{25}$, w których świadectwa mogą być powszechniej doświadczane - urządzeniami, poprzez które oddziaływać mogą one poza wyłącznie fachowym kontekstem.

\section{Abstract}

\section{Maria Kobielska}

JAGIELLONIAN UNIVERSITY (CRACOW)

The Witness at the Exhibition: Testimonies in New Historical Museums

Analysing the functioning of testimonies in current historical museum exhibitions, Kobielska offers examples from the Warsaw Uprising Museum and the Museum of the Second World War in Gdańsk. She takes into account both audio and video media and systematizes the ways in which testimonies are presented. Among the issues explored are the fragmentation of the testimonies, the degree to which the visitor experiences them as optional or obligatory, the physical location of the testimonies in the exhibition space, the way in which they are contextualized and processed, and finally their function in the museum's memory narrative. All these factors shape the visitor's experience, which may be called the "an experience of testimony" or "an experience of the witness". Discussing the strategies for dealing with testimonies at the exhibitions in Poland's new historical museums leads Kobielska to describe the poetics and to question the ethics of "exhibiting the witness".

\section{Keywords}

history museum, video testimony, witness, Museum of the Second World War, Warsaw Uprising Museum

25 Oprócz, przede wszystkim, świadectw wykorzystywanych w filmach dokumentalnych. 